\title{
PENGEMBANGAN PUDING DENGAN PENAMBAHAN TEPUNG WORTEL(Daucus Carrota L) DAN KUNING TELUR SEBAGAI ALTERNATIF SNACK FOOD SUMBER PRO VITAMIN A
}

\author{
Puding Development with the Addition of Carrot Flour (Daucus carrota L) and \\ Yellow Egg as An Alternative Snack Food Source Pro Vitamin A
}

\author{
Sepni Asmira ${ }^{1 *}$, Dezi Ilham², Partini Widiastika ${ }^{2}$ \\ ${ }^{1}$ Prodi D III Gizi, Fikes Upertis \\ ${ }^{2}$ Prodi S I Gizi, Fikes Upertis \\ *sepni.asmira@gmail.com
}

\begin{abstract}
Impaired vision and blindness are still a health problem in the world, including in Indonesia. Efforts to maintain eye health can be done by consuming foods that contain lots of vitamin A or provitamin A. Carrots are a source of provitamin A and egg yolks are a source of fat apart from being a source of vitamin A as well. This study aims to determine the effect of adding carrot flour and egg yolk on organoleptic quality and levels of beta-carotene and fat in pudding. This study is an experimental study using a completely randomized design (CRD) consisting of four treatments and two replications. Observations were made subjectively on taste (organoleptic test) with 25 moderately trained panelists and objective observations included testing the levels of beta-carotene with UV-vis spectrophotometry and fat content testing using the Soxhlet method. Based on the results of the organoleptic test, it was found that the best treatment was treatment B (10:10) with four indicators assessed including color, aroma, texture and taste. The laboratory results showed that the highest beta-carotene content was between sample A (control) and sample B (10:10) with the highest average result in sample $B$ of 50.2 ppm and the highest fat content in sample B was $0.169 \%$. It is recommended to further researchers to test the acceptability of the product and make more use of local food in research besides being easy to find and having high nutritional value and economic value.
\end{abstract}

Key words: pudding, carrot flour, egg yolk, beta-carotene

\section{ABSTRAK}

Gangguan terhadap penglihatan dan kebutaan masih menjadi masalah kesehatan di dunia termasuk di Indonesia. Upaya menjaga kesehatan mata dapat dilakukan dengan asupan makanan yang banyak mengandung vitamin A atau provitamin A. Pangan nabati merupakan pangan sumber provitamin, sebaliknya pangan hewani biasanya mengandung vitamin A. Wortel merupakan bahan pangan sumber provitamin A dan kuning telur merupakan sumber lemak selain sebagai 
sumber vitamin A juga. Penelitian ini bertujuan untuk mengetahui pengaruh penambahan tepung wortel dan kuning telur terhadap mutu organoleptik serta kadar betakaroten dan lemak dalam puding. Penelitian ini merupakan penelitian eksperimen dengan menggunakan desain rancangan acak lengkap (RAL) yang terdiri dari empat perlakuan dan dua kali ulangan. Pengamatan dilakukan secara subjektif terhadap cita rasa (uji organoleptik) dengan 25 orang panelis agak terlatih dan pengamatan secara objektif meliputi uji kadar betakaroten dengan spektrofotometri uv-vis dan uji kadar lemak dengan menggunakan metode soxhlet. Berdasarkan hasil uji organoleptik didapatkan bahwa perlakuan terbaik adalah perlakuan B (10:10) dengan empat indikator yang dinilai meliputi warna, aroma, tekstur dan rasa. Hasil penelitian menunjukkan bahwa kadar betakaroten yang tertinggi antara sampel A (kontrol) dengan sampel B (10:10) dengan hasil rata-rata tertinggi terdapat pada sampel B sebesar 50,2 ppm dan hasil labor kadar lemak yang tertinggi pada sampel B sebesar 0,169 \% Disarankan kepada peneliti selanjutnya untuk melakukan uji daya terima produk dan lebih memanfaatkan pangan lokal dalam penelitian selain mudah dicari dan memiliki nilai gizi dan nilai ekonomis yang tinggi.

Kata kunci : puding, tepung wortel, kuning telur, betakaroten

Submit: 10 Juni $2021 *$ Revisi: 20 Agustus $2021 *$ Accepted:19 September $2021 *$ Publish: 12 November 2021

\section{PENDAHULUAN}

Kesehatan terhadap alat indera manusia merupakan hal utama yang sangat perlu di perhatikan terutama mata, indera penglihatan manusia merupakan alat terpenting untuk menyerap berbagai informasi motorik. Masalah kesehatan di Indonesia yaitu katarak sebesar $52 \%$, glaukoma $13,4 \%$, kelainan refraksi $9,5 \%$, gangguan retina $8,5 \%$, kelainan kornea 8,4 \% [1] dari 266,91 juta jiwa 134 juta jiwa laki-laki dan 132,89 jiwa perempuan [2].

Gangguan penglihatan secara umum dapat diartikan sebagai keadaan penurunan fungsi penglihatan secara menetap yang tidak dapat diperbaiki dengan obat-obatan, pembedahan atau kacamata atau penyempitan lapang pandang bilateral [3]. Salah satu upaya menjaga kesehatan mata dengan makanan yang banyak mengandung vitamin A . Vitamin A yang terdapat pada pangan nabati seperti sayuran dan buah-buahan berwarna kuning jingga seperti wortel, labu, bayam, pepaya, dan lain-lain [4].

Vitamin A merupakan zat gizi penting (essensial) bagi manusia karena tidak dapat diproduksi sendiri didalam tubuh umumnya tubuh mendapat asupan vitamin A dari luar seperti mengkonsumsi kuning telur, bahan makanan yang diperkaya vitamin A.

Wortel merupakan jenis sayuran yang menyehatkan untuk tubuh manusia selain enak dan digemari oleh masyarakat. Produktivitas wortel mengalami peningkatan sebesar 10.207 ton pada tahun 2019 dari tahun 2018 yang produksinya sebanyak 31271 ton untuk provinsi Sumatera Barat [2]. Selain kandungan vitamin A dari wortel yang baik untuk kesehatan mata, wortel juga mengandung pigmen betakaroten 
yang memberi warna orange pada buah dan sayuran. Kadar betakaroten yang terkandung dalam wortel lebih banyak dibandingkan kangkung, sawi, dan bayam. Betakaroten ini dapat mencegah dan mengatasi kanker, darah tinggi, menurunkan kadar kolesterol. Kandungan tinggi antioksidan karoten juga terbukti dapat memerangi efek polusi dan perokok pasif [5].

Selain wortel, kuning telur juga merupakan bahan pangan sumber karoten dan lemak. Kuning telur mengandung lemak yang sangat baik untuk penambahan energi, tiap $100 \mathrm{~g}$ kuning telur menghasilkan lemak sebanyak 31,90 g.

Telur sangat mudah untuk dijumpai dalam kehidupan sehari-hari selain mudah ditemukan telur juga banyak manfaatnya untuk kesehatan baik, putih telur maupun kuning telurnya. Telur sering dijadikan bahan dalam pembuatan berbagai jenis makanan, diantaranya dalam pembuatan puding. Kombinasi wortel dan telur ini potensi dikembangkan dalam pembuatan puding agar menghasilkan puding dengan kadar betakaroten optimal. Berdasarkan penjelasan dari data diatas penelitian ini melakukan pengembangan produk puding dengan penambahan tepung wortel (Daucus carrota l) dan kuning telur sebagai alternatif snack food sumber pro vitamin A.

\section{METODE PENELITIAN}

\section{Desain Penelitian}

Desain penelitian ini adalah penelitian eksperimental dengan perlakuan penambahan tepung wortel dan kuning telur pada pembuatan puding dengan masing-masing perlakuan berbeda. Dengan penambahan tepung wortel dan kuning telur konsentrasi (10:10), (20:10), (30:10) serta kontrol puding tanpa penambahan tepung wortel dan kuning telur .

\section{Waktu dan Tempat Penelitian}

Analisis kadar $\beta$-karoten dilakukan di Laboratorium Biokimia Fakultas Kedokteran Universitas Andalas dan analisis kadar lemak yang akan dilakukan di Laboratorium Kimia Fakultas FMIPA Universitas Negri Padang.

\section{Alat dan Bahan}

\section{Alat}

Alat yang digunakan dalam penelitian ini adalah panci, timbangan, sendok pengaduk, cetakan agar. Alat yang digunakan dalam uji kadar betakaroten dalam penelitian ini adalah spatula, erlenmeyer, gelas ukur, batang pengaduk, setrifuge, lumpang dan alu, spektofotometer, mikropipet, timbangan analitik, dan spektrofotometer UV-Vis (spektronik 21-D).

Alat yang digunakan dalam penelitian ini adalah soxhlet beserta kondensornya, labu lemak, kertas saring, mortar, timbangan analitik. Alat yang digunakan dalam pengujian organoleptik adalah formulir pengujian.

Bahan yang dipakai dalam pembuatan tepung wortel dalam penelitian ini adalah wortel dan air.

Bahan yang dipakai dalam penelitian ini adalah agar-agar plain, tepung susu,gula pasir, kuning telur, garam, vanili, tepung wortel

\section{Bahan}

Bahan yang digunakan dalam uji kada beta karoten ini adalah sampel 
puding, 5 gram, $\beta$-karoten induk, eter, dan aseton. Bahan yang digunakan dalam pengujian kadar lemak dengan metode soxhlet ini adalah sampel pudding dan hexan (pelarut lemak).

\section{Rancangan dan Analisis Data}

Rancangan penelitian ini menggunakan rancangan acak lengkap (RAL) dengan 4 perlakuan dan 2 kali pengulangan.

Data dianalisis menggunakan analisis sidik ragam (ANOVA) 5\%. Jika terdapat perbedaan nyata antara perlakuan maka dilakukan uji lanjut yaitu dengan menggunakan uji Duncan New Multiple Range (DNMRT) pada taraf $5 \%$.

\section{Pengamatan}

Pengamatan dilakukan dengan dua cara yaitu secara subjektif dan secara objektif. Secara subjektif dilakukan uji organoleptik oleh 25 orang panelis agak terlatih, yaitu mahasiswa jurusan gizi yang telah mendapatkan mata kuliah ilmu teknologi pangan (ITP). Uji organoleptik yang digunakan adalah uji hedonik yang meliputi warna, aroma, tekstur, rasa, dengan skala $1-5$. Uji kadar betakaroten dengan metode Spektrofotometri Uv-Vis.

\section{HASIL DAN PEMBAHASAN}

\section{Hasil Uji Organoleptik}

Pengaruh uji organoleptik pada penambahan tepung wortel dan kuning telur terhadap puding terdapat pada Tabel 1.

\section{Hasil Perlakuan Terbaik}

Nilai rata-rata warna, aroma, tekstur dan rasa dari puding tepung wortel dan kuning telur pada berbagai perlakuan dapat dilihat pada Tabel 1 .

Tabel 1 Rata-rata Hasil Uji Organoleptik

\begin{tabular}{|l|c|c|c|c|c|c|}
\hline \multicolumn{1}{|c|}{ Perlakuan } & Warna & Aroma & Tekstur & Rasa & Jumlah & Rata-rata \\
\hline Kontrol $(\mathrm{A})$ & 1,08 & 4,2 & 3,6 & 3,64 & 12,52 & 3,13 \\
\hline $\mathrm{B}(10 \mathrm{~g}: 10 \mathrm{~g})$ & 2,68 & 3,92 & 3,52 & 4,08 & 14,2 & 3,55 \\
\hline $\mathrm{C}(20 \mathrm{~g}: 10 \mathrm{~g})$ & 3,04 & 3,88 & 3,28 & 3,36 & 13,56 & 3,39 \\
\hline D $(30 \mathrm{~g}: 10 \mathrm{~g})$ & 3,52 & 3,76 & 2,56 & 3,08 & 12,92 & 3,23 \\
\hline
\end{tabular}

Berdasarkan Tabel 1 terlihat bahwa nilai rata-rata terhadap warna, aroma, tekstur dan rasa perlakuan pertama dengan kode $\mathrm{B}$ (10 g tepung wortel : $10 \mathrm{~g}$ kuning telur) berada pada tingkat suka dengan rata-rata tertinggi sebesar 3,95.

\section{Hasil Uji Hedonik}

\section{Hedonik Warna}

Nilai rata-rata kesukaan panelis terhadap warna puding dengan penambahan kuning telur dan wortel yang diberikan panelis berkisar antara 3,68 sampai 4,4 pada puding tepung wortel dimana skor 5 adalah skor yang paling tinggi pada tingkat kesukaannya. Warna yang paling disukai adalah 
perlakuan D dengan perbandingan (tepung wortel $30 \mathrm{~g}$ dengan kuning telur $10 \mathrm{~g}$ ) dengan nilai $4,40 \%$.

Berdasarkan uji Anova didapatkan nilai $\mathrm{F}$ hitung $(3,86)$ kemudian dibandingkan dengan $\mathrm{F}$ tabel yang bernilai $(2,76)$ pada taraf $5 \%$ ternyata $\mathrm{F}$ hitung lebih besar dibandingkan $\mathrm{F}$ tabel sehingga dapat dinyatakan bahwa terdapat perbedaan nyata antar perlakuan. Kemudian dilanjutkan dengan Duncan New Multiple Range Test (DNMRT) pada taraf uji 5\% didapatkan hasih bahwa terdapat perbedaan nyata antar perlakuan D dengan B dan C.

\section{Aroma}

Nilai rata-rata kesukaan panelis terhadap aroma puding dengan penambahan kuning telur dan wortel yang diberikan panelis berkisar antara 3,52 sampai 3,84 pada puding tepung wortel dimana skor 5 adalah skor yang paling tinggi pada tingkat kesukaannya. Aroma yang paling disukai adalah perlakuan A tanpa penambahan dengan nilai rata-rata $3,84 \%$.

Berdasarkan hasil uji Anova didapatkan nilai $F$ hitung $(1,75)$ dan $F$ tabel $(2,76)$ maka dapat dinyatakan tidak terdapat perbedaan nyata antar perlakuan.

\section{Tekstur}

Berdasarkan hasil uji Anova didapatkan nilai $\mathrm{F}$ hitung $(4,75)$ kemudian dibandingkan dengan $\mathrm{F}$ tabel $(2,76)$ pada taraf $5 \%$ ternyata $\mathrm{F}$ hitung lebih besar dibandingkan $\mathrm{F}$ tabel sehingga dapat dinyatakan bahwa terdapat perbedaan nyata antar perlakuan. Hasil uji kemudian dilanjutkan dengan uji Duncan New Multiple Range Test (DNMRT) pada taraf uji 5\% di dapatkan perlakuan A dan $B$ berbeda nyata dengan $C$ dan $D$.

\section{Rasa}

Nilai rata-rata kesukaan panelis terhadap rasa puding dengan penambahan kuning telur dan wortel yang diberikan panelis berkisar antara 3,60 sampai 4,44 pada puding tepung wortel dimana skor 5 adalah skor yang paling tingkat kesukaannya lebih tinggi. Tekstur yang paling disukai adalah perlakuan $\mathrm{B}$ dengan penambahan (tepung wortel $10 \mathrm{~g}$ dan kuning telur 10 g) dengan nilai rata-rata $4,44 \%$.

Berdasarkan hasil uji Anova didapatkan nilai $\mathrm{F}$ hitung $(7,18)$ kemudian dibandingkan dengan $\mathrm{F}$ tabel $(2,76)$ pada taraf $5 \%$ ternyata $\mathrm{F}$ hitung lebih besar dibandingkan $F$ tabel sehingga dapat dinyatakan bahwa terdapat perbedaan nyata antar perlakuan. Hasil uji kemudian dilanjutkan dengan uji Duncan New Multiple Range Test (DNMRT) pada taraf uji 5\% didapatkan perlakuan A berbeda nyata dengan $\mathrm{B}, \mathrm{C}$ dan $\mathrm{D}$.

\section{Hasil Perlakuan Terbaik}

\section{Uji Kadar Betakaroten}

Setelah mendapatkan perlakuan terbaik dari hasil uji organoleptik, yaitu perlakuan B selanjutnya dilakukan uji kadar betakaroten dengan metode Spektrofotometri Uv-Vis. Sampel pudding pada perlakuan B (penambahan $10 \mathrm{~g}$ tepung wortel : $10 \mathrm{~g}$ kuning telur), berdasarkan analisis deskriptif didapatkan hasil nilai maksimum sampel dengan A sebesar 4,8 dan sampel B 50,2 sehingga dapat diketahui ada hubungan antara perlakuan .

Kecukupan untuk betakaroten perhari dalam sampel B tersebut sudah 
mencukupi pemenuhan asupan dari zat gizi betakaroten, batas konsumsi betakaroten per hari untuk dewasa yaitu sebanyak 7-15 mg sedangkan anak anak batas normalnya adalah 3 - $6 \mathrm{mg}$ per hari. Pemenuhan asupan zat gizi tersebut ditujukan sebagai upaya pencegahan terhadap berbagai penyakit mata.

\section{Uji kadar Lemak}

Setelah mendapatkan perlakuan terbaik dari hasil uji organoleptik, yaitu perlakuan B selanjutnya dilakukan uji kadar lemak dengan metode soxhlet. Didapatkan kadar lemak dalam puding pada perlakuan A penambahan tepung wortel dan kuning telur sebanyak $0 \mathrm{~g}: 0 \mathrm{~g}$ dan sampel perlakuan $B$ dengan penambahan $10 \mathrm{~g}$ tepung wortel dan $10 \mathrm{gr}$ kuning telur, berdasarkan hasil analisis deskriptif didapatkan hasil dari sampel A nilai maksimum sebesar $0,169 \mathrm{mg}$ dan sampel B sebesar 0,289 mg sehingga dapat diketahui bahwa ada hubungan antara perlakuan.

Asupan tersebut masih kurang untuk atlet olahraga karena batas normal kecukupan lemak untuk atlet adalah sebanyak $20-30 \%$ dari kebutuhan lemak perharinya, karena tubuh atlet juga harus di seimbangi dengan karbohidrat dan protein kecukupan tersebut berdasarkan aktivitas fisik yang dilakukan oleh atlet untuk itu perlunya tambahan lemak dari makanan pokok kemudian ditambah dengan makanan selingan.

\section{PEMBAHASAN}

\section{Uji Mutu Hedonik}

Uji mutu hedonik adalah uji yang dilakukan untuk mengetahui warna, aroma, tekstur dan rasa pada puding dengan penambahan tepung wortel dan kuning telur, untuk mendapatkan uji hedonik diperlukan panelis terlatih sebanyak 25 orang.

\section{Warna}

Warna merupakan sifat pertama yang dapat diamati oleh konsumen karena warna merupakan kenampakan yang akan lebih dahulu dinilai dengan mata. Warna makanan memiliki peran utama dalam penampilan makanan, meskipun makanan tersebut lezat, tetapi jika penampilan tidak menarik akan menyebabkan selera konsumen menjadi hilang.

Hasil penelitian uji mutu hedonik warna dari puding dengan penambahan tepung wortel dan kuning telur. Nilai tertinggi yang disukai panelis terhadap warna pada perlakuan D memperoleh penilaian dengan skor rata-rata 3,52 dengan kategori oren . Hal ini disebabkan karena warna dari puding diperoleh dari penambahan tepung wortel sebanyak $30 \mathrm{~g}$ dan kuning telur 10gr sedangkan puding yang memiliki nilai rata-rata ter rendah adalah 1,08 pada perlakuan A tanpa penambahan $(0 \mathrm{~g}$ : 0g) dengan kategori warna putih. Penerimaan panelis terhadap warna puding semakin meningkat dan semakin banyak penambahan tepung wortel maka warna puding akan semakin orange.

\section{Aroma}

Indikator kedua adalah aroma, penilaian terhadap aroma bahan pangan merupakan evaluasi dengan penciuman. Penelitian oleh [6] aroma dodol yang disubstitusi tepung wortel menghasilkan aroma yang cukup disukai. Aroma makanan banyak menentukan kelezatan makanan tersebut oleh karena itu aroma 
merupakan salah satu penentuan dalam mutu. Pada umumnya bau yang diterima oleh hidung dan otak lebih banyak ramuan atau campuran tiga bau utama yaitu, harum, asam, dan tengik. Aroma makanan menentukan kelezatan makanan tersebut.

Nilai rata-rata kesukaan panelis adalah puding yang dibuat tanpa perlakuan sampel A dengan nilai 4,20 berada dalam kategori suka dengan kategori harum sedangkan aroma yang mendapat nilai rata-rata terendah yaitu 3,76 pada perlakuan $\mathrm{D}$ (penambahan $30 \mathrm{~g}$ tepung wortel : $10 \mathrm{~g}$ kuning telur).

\section{Tekstur}

Indikator ketiga adalah tekstur, penilaiana pada tekstur makanan dapat dilakukan dengan jari, gigi, dan langitlangit (palantum), dan nilai yang diperoleh diharapkan dapat diketahui kualitas makanan. Faktor tekstur diantaranya adalah rabaan oleh tangan, keempukan, kerenyahan, kekerasan dan kekenyalan.

Nilai rata-rata kesukaan panelis adalah puding yang dibuat dengan perlakuan A tanpa penambahan yaitu sebesar 3,6 dan rata-rata terendah dengan kategori kenyal pada perlakuan $\mathrm{D}$ (penambahan $30 \mathrm{~g}$ tepung wortel : $10 \mathrm{~g}$ kunig telur) yaitu 2,56 dengan kategori padat hal tersebut disebabkan karena penambahan tepung wortel pada puding sehingga mengurangi tingkat kekenyalan pada puding.

\section{Rasa}

Indikator terakhir adalah rasa. Rasa merupakan bagian rangsangan yang dirasakan indra pengecap. Rasa merupakan faktor yang paling penting dalam menentukan keputusan baik konsumen untuk menerima atau menolak suatu makanan. Produk makanan yang mempunyai warna, aroma, tekstur, dan nilai gizi yang baik akan di tolak jika rasa tidak enak. Rasa memiliki empat macam, yaitu manis, pahit, asam dan asin [7].

Hasil uji mutu hedonik rata-rata kesukaan panelis adalah puding yang dibuat dengan perlakuan B (penambahan $10 \mathrm{~g}$ tepung wortel : $10 \mathrm{~g}$ kuning telur) dengan nilai 4,08 berada dalam kategori suka dengan tingkat rasa manis dan gurih seimbang, dan rata-rata hedonik rasa yang terendah adalah perlakuan $\mathrm{D}$ (penambahan $30 \mathrm{~g}$ tepung wortel : $10 \mathrm{~g}$ kuning telur) yaitu 3,08. Rasa yang ditimbulkan dari tepung wortel dengan penambahan $30 \mathrm{~g}$ membuat cita rasa puding berkurang karena kandungan tepung wortel dalam puding memiliki serat lebih banyak.

\section{Uji Hedonik}

Uji hedonik merupakan pengujian yang paling banyak digunakan untuk mengukur tingkat kesukaan terhadap sebuah produk. Tingkat kesukaan ini disebut dengan skala hedonik misalnya sangat suka, suka, agak suka, agak tidak suka, tidak suka, sangat tidak suka dan lain-lain. Skala hedonik yang digunakan :

$$
\begin{array}{ll}
1=\text { Tidak suka } & 4=\text { Suka } \\
2=\text { Kurang suka } & 5=\text { Sangat suka }
\end{array}
$$$$
3=\text { Agak suka }
$$

Uji ,mutu hedonik adalah uji dimana panelis menyatakan kesan pribadi tentang baik atau buruk (kesan mutu hedonik). Kesan mutu hedonik lebih spesifik dari kesan suka atau tidak suka dan dapat bersifat lebih umum. Contoh kesan mutu hedonik dari suatu produk adalah kesan sepet tidaknya minuman teh, pulen keras nasi, dan empuk keras dari daging [8]. 


\section{Warna}

Warna merupakan sensori pertama yang dapat dilihat langsung oleh panelis. Penentuan mutu bahan makanan umumnya bergantung pada warna yang dimilikinya, warna yang tidak menyimpang dari warna yang seharusnya akan memberi kesan penilaian tersendiri oleh panelis.

Hasil penelitian penerimaan panelis menunjukkan nilai rata-rata terhadap warna puding berada pada range tidak suka, kurang suka, agak suka, suka, sangat suka dengan penambahan tepung wortel dan kuning telur berkisar 1,08 sampai 3,64 warna yang paling disukai adalah perlakuan D dengan penambahan tepung wortel dan kuning telur sebanyak (10g: $10 \mathrm{~g}$ ) dengan nilai rata-rata $(4,44)$

Berdasarkan uji Anova didapatkan nilai $F$ hitung $(3,86)$ kemudian dibandingkan dengan $F$ tabel yang bernilai $(2,76)$ pada taraf $5 \%$ ternyata $\mathrm{F}$ hitung lebih besar dibandingkan $\mathrm{F}$ tabel sehingga dapat dinyatakan bahwa terdapat perbedaan nyata antar perlakuan. Kemudian dilanjutkan dengan Duncan New Multiple Range Test (DNMRT) pada taraf uji 5\% didapatkan hasih bahwa terdapat perbedaan nyata antar perlakuan D dengan B dan C .

\section{Aroma}

Hasil penelitian penerimaan panelis menunjukkan nilai rata-rata terhadap aroma puding berada pada range tidak suka, kurang suka, agak suka, suka, sangat suka dengan penambahan tepung wortel dan kuning telur berkisar 3,52 sampai 3,84 aroma yang paling disukai adalah sampel A tanpa perlakuan $(0 \mathrm{~g}: 0 \mathrm{~g})$.

Berdasarkan hasil uji Anova didapatkan nilai $\mathrm{F}$ hitung $(1,75)$ dan $\mathrm{F}$ tabel $(2,76)$ maka dapat dinyatakan tidak terdapat perbedaan nyata antar perlakuan. Kemudian dilanjutkan dengan Duncan New Multiple Range Test (DNMRT) pada taraf uji 5\% didapatkan hasih bahwa tidak terdapat perbedaan nyata antar perlakuan.

\section{Tekstur}

Tekstur adalah salah satu sifat bahan atau produk yang dapat dirasakan melalui sentuhan kulit ataupun pencicipan. Beberapa sifat tekstur dapat juga diperkirakan dengan menggunakan sebelah mata (berkedip) seperti kehalusan atau kekerasan dari permukaan bahan atau kekentalan pada cairan sedangkan dengan suara atau bunyi dapat diperkirakan tekstur dari kerupuk (crisp food).

Hasil penelitian penerimaan panelis menunjukkan nilai rata-rata terhadap tekstur puding berada pada range tidak suka, kurang suka, agak suka, suka, sangat suka dengan penambahan tepung wortel dan kuning telur berkisar 3,12 sampai 3,68 tekstur yang paling disukai adalah perlakuan B dengan penambahan tepung wortel dan kuning telur sebanyak $10 \mathrm{~g}: 10 \mathrm{~g}$ dengan nilai rata-rata 3,68.

Berdasarkan hasil uji Anova didapatkan nilai $\mathrm{F}$ hitung $(4,75)$ kemudian dibandingkan dengan $\mathrm{F}$ tabel $(2,76)$ pada taraf $5 \%$ ternyata $\mathrm{F}$ hitung lebih besar dibandingkan $F$ tabel sehingga dapat dinyatakan bahwa terdapat perbedaan nyata antar perlakuan. Hasil uji kemudian dilanjutkan dengan uji Duncan New Multiple Range Test (DNMRT) pada taraf uji 5\% di dapatkan perlakuan A dan $B$ berbeda nyata dengan $C$ dan $D$. 


\section{Rasa}

Rasa merupakan salah satu sifat dari makanan, minuman dan bumbu yang dapat di defenisikan kumpulan hasil presepsi dari stimulasi indera yang digabungkan dengan stimulasi pencernaan berupa kesan yang diterima dari suatu produk yang ada di mulut. Rasa makanan menjadi aspek yang paling sulit dinilai secara akurat karena memiliki sifat subjektif, sehingga penilaian tersebut berdasarkan dengan selera panelis yang mencicipinya.

Hasil penelitian penerimaan panelis menunjukkan nilai rata-rata terhadap rasa puding berada pada range tidak suka, kurang suka, agak suka, suka, sangat suka dengan penambahan tepung wortel dan kuning telur berkisar 3,6 sampai 4,44 rasa yang paling disukai adalah perlakuan $\mathrm{B}$ dengan penambahan tepung wortel dan kuning telur sebanyak $10 \mathrm{~g}: 10 \mathrm{~g}$ dengan nilai rata-rata 4,44 . Hasil ini sejalan dengan penelitian [9] yang membuat crackers dengan penambahan tepung ikan patin dan tepung wortel sebanyak masingmasing $25 \mathrm{~g}$ dengan produk yang paling disukai oleh panelis menggunakan evaluasi metode score yaitu dengan nilai 3,56 dari 5 .

\section{Kadar Betakaroten}

Puding yang terbaik yaitu puding yang dibuat dengan perlakuan $B$ (penambahan $10 \mathrm{~g}$ tepung wortel : $10 \mathrm{~g}$ kuning telur) yang memiliki kadar betakaroten berdasarkan analisis deskriptif didapatkan hasil nilai maksimum sampel dengan A sebesar 4,8 dan sampel B 50,2 sehingga dapat diketahui ada hubungan antara perlakuan. Hal ini sesuai dengan penelitian [10] penambahan tepung wortel pada sosis ikan gabus perlakuan yang paling disukai oleh panelis adalah penambahan $10 \mathrm{~g}$ tepung wortel.

\section{Kadar Lemak}

Puding yang terbaik yaitu puding dengan perlakuan $\mathrm{B}$ dengan penambahan $10 \mathrm{~g}$ tepung wortel : $10 \mathrm{~g}$ kuning telur, hasil analisis deskriptif didapatkan hasil dari sampel A nilai maksimum sebesar 0,169 dan sampel B sebesar 0,289. Hasil penambahan $10 \mathrm{~g}$ kuning telur tersebut sudah memenuhi 28,9 \% kecukupan lemak.

\section{KESIMPULAN}

Berdasarkan uji yang dilakukan dapat disimpulkan formulasi terbaik dari puding dengan penambahan tepung wortel dan kuning telur adalah perlakuan $\mathrm{B}$ (penambahan $10 \mathrm{~g}$ tepung wortel : 10 g kuning telur) karena memiliki nilai rata-rata tertinggi dari hasil uji mutu hedonik. Kadar betakaroten sampel B 50,2 dan hasil laboratorium kadar lemak pada sampel B sebesar 0,289\%. Puding yang dikembangkan dari tepung wortel dan penambahan telur ini potensi sebagai snack alternative sumber betakaroten

\section{DAFTAR PUSTAKA}

[1] Kemenkes, R.I., Situasi dan Analisis Glaukoma. 2011, Pusat Data dan Informasi: Jakarta.

[2] BPS, Data Sensus Kependudukan. 2018, Badan Pusat Statistik Indonesia.

[3] Staff, A.A., Conjunctivitis-The Eye. 2010, M.D. Association. p. 15.

[4] Almatsier, S., Prinsip Dasar Ilmu Gizi. 2002, Jakarta: PT. Gramedia Pustaka Utama. 
[5] Anonim, Analisis Betakaroten pada Wortel. 2011.

[6] Utami, S.I., Pengaruh Substitusi Tepung Wortel terhadap Mutu Organoleptik dan Kadar Betakaroten Dodol. 2005, Poltekkes Kemenkes: Padang.

[7] Diniyati, B., Kadar Betakaroten, Protein, Tingkat Kekerasan, dan Mutu Organoleptik Mie Instan dengan Substitusi Tepung Ubi Jalar Merah (Ipomoe batatas) dan Kacang Hijau (Vigna radiata). 2012, Universitas Diponegoro: Semarang.

[8] Saraswati, Uji Bakteri Salmonella Sp. pada Telur Bebek, Telur Ayam
Kampung. 2012, Universitas Negeri Gorontalo: Gorontalo.

[9] Arza, P.A. and M. Tirtavani, Pengembangan Crackers dengan Penambahan Tepung Ikan Patin (Pangasius hypophthalmus) dan Tepung Wortel (Daucus carota L). Jurnal Penelitian Gizi dan Makanan, 2017. 40(2): p. 55-62.

[10] Singal, C., Pengaruh Penambahan Tepung Wortel (daucus carrota L) pada Pembuatan Sosis Ikan gabus (opiocephalus striatus). Jurnal Teknologi Pertanian Universitas Hasanudin, 2012. 3(4): p. 4-6. 